\title{
Correction to: Pyrenophora teres growth and severity of net blotch on barley under salt stress
}

\author{
Amani Ben Alaya • Fatma Rabhi • Kamel Hessini • Naceur Djébali
}

Published online: 24 December 2021

(C) Koninklijke Nederlandse Planteziektenkundige Vereniging 2021

\section{Correction to: Eur J Plant Pathol.}

https://doi.org/10.1007/s10658-021-02355-Z

This correction is published as author Kamel Hessini affiliations were not fully mentioned and needs to be read as:

Department of Biology, College of Sciences, Taif University, P.O. Box 11,099, Taif 21,944, Saudi Arabia.

Original article has been updated.

The online version of the original article can be found at https://doi.org/10.1007/s10658-021-02355-z

\footnotetext{
A. B. Alaya $\cdot$ F. Rabhi $\cdot$ N. Djébali $(\bowtie)$

Laboratory of Bioactive Substances, Centre of Biotechnology of Borj Cedria, BP 901, 2050 Hammam-Lif, Tunisia

e-mail: dnaceur2014@gmail.com

K. Hessini

Department of Biology, Faculty of Science, University of Taif, P.

O. Box 11099, Taif 21944, Saudi Arabia
}

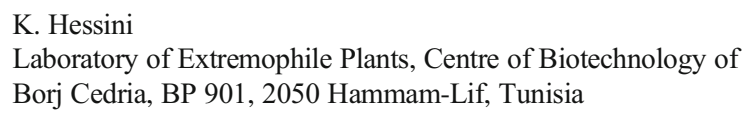

